\title{
Perbaikan Fasilitas Kerja Untuk Mengurangi Keluhan Musculoskeletal Pada Pekerja Di CV. XYZ
}

\author{
Chalis Fajri Hasibuan ${ }^{1}$, Kamil Mustafa ${ }^{2}$, Doni Marthondi Siregar ${ }^{3}$ \\ ${ }^{123}$ Program Studi Teknik Industri, Fakultas Teknik \\ Universitas Medan Area, Indonesia \\ chalisfajri@yahoo.co.id
}

\begin{abstract}
Abstrak
Keluhan pada sistem muskuloskeletal adalah keluhan yang dirasakan oleh seseorang pada bagian otot dan rangka dengan tingkat keluhan yang berbeda - beda, keluhan hingga kerusakan ini yang biasanya diistilahkan dengan gangguan muskuloskeletal. Pada umumnya gangguan muskuloskeletal terjadi apabila sistem muskuloskeletal menerima beban yang melampaui kapasitasnya dengan durasi pembebanan yang panjang. Pembebanan berlebih pada otot yang menyebabkan otot mengalami kontraksi melebihi $20 \%$ dari kekuatan maksimumnya, yang akan berdampak pada kurangnya peredaran darah ke otot. Adapun Tujuan dari penelitian ini adalah untuk mengevaluasi Perbaikan Fasilitas Kerja Pada Alat Pengkilap Panci Untuk Memperbaiki Postur Kerja Pada Perusahan CV. XYZ. Pengukuran ini dilakukan dengan menggunakan metode Rapid Entire Body Assessment (REBA ) dan menggunakan Standard Nordic Questionnaire ( SNQ) sebagai instrument penelitian . Penelitian dilakukan dengan metode survei analitik yang bertujuan untuk melihat adanya hubungan antara sikap kerja dengan keluhan musculoskeletal dengan pendekatan cross sectional. Dari hasil kuesioner SNQ pada 6 orang pekerja menunjukkan bahwa keluhan muskuloskeletal yang dialami pekerja pengkilap panci berada pada kategori sakit terbanyak adalah pada leher atas dan leher bawah sebanyak 4 (66,7\%). Pada kategori sangat sakit terbanyak adalah pada tangan kanan dan pergelangan tangan kanan, tangan kiri dan pergelangan tangan kiri sebanyak 6(100\%). Berdasarkan pengukuran dengan metode Rapid Entire Body Assessment REBA dan Uji Chi-Square, dinyatakan terdapat skor REBA di antara 8 - 11 dimana skor tersebut berada pada daerah beresiko tinggi terhadap gangguan musculoskeletal dan pada skor REBA usulan yang dilakukan terdapat skor 5 dimana skor tersebut berada pada daerah beresiko Rendah. Sehingga untuk menanggulangi sikap kerja dan postur kerja yang salah berakibat pada timbulnya keluhan musculoskeletal diusulkan sebuah rancangan modifikasi alat kerja yaitu mesin pengkilap panci untuk menekan tingginya angka keluhan muscukuloskeletal pada pekerja pengkilap panci.
\end{abstract}

Kata Kunci : Muskuloskeletal, Rapid Entire Body Assessment (REBA), Pengkilap Panci, Desain Fasilitas

\section{PENDAHULUAN}

Pada era globalisasi saat ini perkembangan industri sangat mengalami peningkatan. Indonesia telah menjadi produsen dan eksportir terbesar di seluruh dunia. Sehingga beberapa perusahaan di indonesia terus berupaya untuk meningkatkan kinerja dan produktivitasnya. Untuk mendukung meningkatnya kinerja dan produktivitas maka diperlukannya standar yang baik serta mendapat dukungan yang baik dari tenaga kerja yang sehat dan produktif. (Rahim, M.R. 2013)
Tenaga kerja harus menjadi perhatian perusahaan karena tenaga kerja merupakan sumber daya manusia yang menentukan hasil produksi perusahaan. Jika sumber dayanya tidak dapat bekerja secara maksimal, maka perusahaan tidak mungkin bisa menghasilkan hasil yang maksimal. Salah satu penyebab tidak maksimalnya hasil yang diperoleh di akibatkan oleh faktor kelelahan. (Hardianto, I. Yassierli. 2014)

$\begin{array}{llr}\text { Kelelahan ( } & \text { Fatigue ) adalah } \\ \text { suatu mekanisme perlindungan tubuh } & \text { lebih }\end{array}$


lanjut sehingga terjadi pemulihan setelah istirahat. Istilah kelelahan biasanya menunjukkan kondisi yang berbeda-beda dari setiap individu, tetapi semuanya bermuara kepada kehilangan efisiensi dan penurunan kapasitas kerja serta ketahanan tubuh. Hal ini menunjukkan bahwa kelelahan berperan dalam menjaga homeostatis tubuh. Kelelahan yang sering terjadi pada pekerja yaitu pada otot. (Bukhori, E. 2010)

Lama waktu otot quadricepssaat melakukan gerakan maksimal dalam latihan hanya sampai 30 menit. Kelelahan jenis ini juga berguna sebagai tandabahaya, bahwa otot tidak dapat menerima perintah untuk berkontraksi. Selain itu, kelelahan otot juga memberi sinyal bagi tubuh kita agar beristirahat sejenak untuk mengembalikan keadaan otot setelah terjadi kontraksi yang cukup lama. (Anies, 2014)

Kelelahan otot salah satu faktor peyebabnya adalah adanya interaksi manusia dengan mesin dan peralata yang tidak sesuai dengan posisi tubuh dan antropometri tubuh. Interaksi manusia mesin sering terjadi pada mesin manual dan semi manual, penggunaan alat yang manual dan semi sering terjadi pada UKM. salah satunya adalah pada UKM CV.XYZ Medan Pancing.

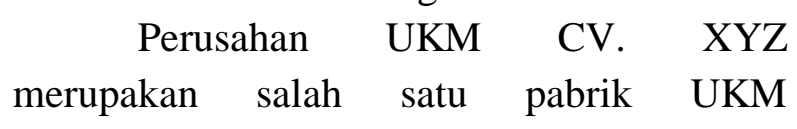
pembuatan priuk di Medan. Pekerjaan yang dilakukan para pekerja di pabrik adalah melakukan Pembuatan proses dari awal pembuatan panci sampai barang jadi. Proses kerja pembuatan dimulai dari peleburan alumanium, pencetakan, pemolesan panci, pembuatan besi pegangan dan tutup dan pengepakan panci.

Berdasarkan survey dan wawancara singkat kepada para pekerja di pabrik tersebut, didapatkan bahwa waktu kerja adalah 8 jam dalam satu hari, mulai dari pukul 08.30 - 18.30 dengan waktu istirahat hanya sekali selama 30 menit yaitu pukul 12.00-12.30, walaupun banyak pekerja yang tidak tetap waktu istirahatnya. Rata -rata pekerja yang bekerja di pabrik tersebut sudah bekerja selama kurang lebih 15 tahun.

Melalui pengamatan singkat dilihat bahwa pekerja CV. XYZ, tersebut bekerja dengan posisi berdiri dan membungkuk secara terus menerus selama 8 jam dalam satu hari waktukerja.

Dan juga berdasarkan SNQ di UKM tersebut terdapat adanya kelelahan pada bagian tubuh lengan atas, lengan bawah,dan kaki. Hal ini dikarenakan interaksi pada mesin. Pelajaran yang paling bertambah pada bagian pemolesan panci sehingga perlu adanya perbaikan desain mesin tersebut.

Berdasarkan uraian tersebut, penulis tertarik melakukan penelitian mengenai Perbaikan Fasilitas Kerja Pada Alat Pengkilap Panci Untuk Memperbaiki Postur Kerja Pada Perusahan CV.XYZ.

Adanya keluhan muskuloskeletal pada pekerja pengkilap panci di CV.XYZ. Untuk mengetahui tingkat kategori resiko keluahan muskuloskelal pada pekerja pengkilap panci pada CV. XYZ sehingga perlu dilaksanakan perbaikan fasilitas kerja untuk mengurangi keluhan musculoskeletal pada pekerja.

\section{METODE PENELITIAN}

Penelitian ini dilakukan di Perusahan CV. XYZ. Waktu penelitian dilaksanakan pada Oktober 2017. Objek yang diteliti adalah mesin / peralatan panci yang berada di area pabrik UKM yaitu mesin pengkilap panci. Penelitian dilakukan dengan metode survei analitik yang bertujuan untuk melihat adanya hubungan antara sikap kerja dengan keluhan muskuloskeletal dengan pendekatan cross 
sectional dimana variabel dependen dan variabel ini diukur dalam satu waktu. Pendekatan ini digunakan untuk melihat hubungan antara variabel satu dengan variabel yang lain. Variabel independen dalam penelitian ini adalah sikap kerja dan variabel dependen penelitian ini adalah keluhan muskuloskeletal.

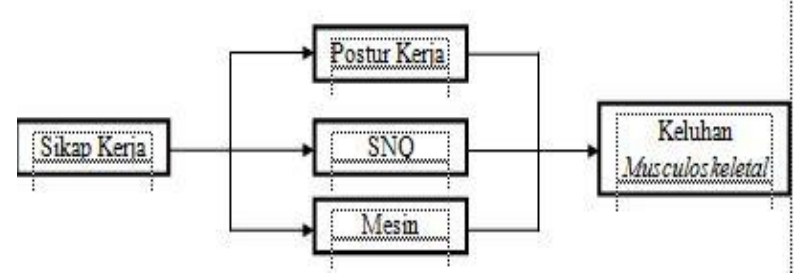

Gambar. 1 Kerangka Konsep Penelitian

$$
\text { Sumber : Hasil Penelitian }
$$

Metode yang digunakan dalam memperoleh data primer tersebut adalah dengan wawancara dan kegiatan tanya jawab dengan pekerja secara langsung di lapangan dan menggunakan alat tulis untuk mencatat data - data yang diperlukan. Metode data skunder tersebut dilakukan dengan melihat dan mencatat dokumen yang ada di perusahan. Data yang telah diperoleh, dianalisis melalui proses pengolahan data yang mencakup kegiatan-kegiatan sebagai berikut :

1. Pengukuran Keluhan sakit dengan menggunakan Standard Nordic Quetionaire (SNQ)

2. Pengukuran Postur Kerja dengan menggunakan Rapid Entire Body Asessment (REBA)

3. Pengolahan Data Antropometri.

Data antropometri yang digunakan adalah leher bahu, tinggi bahu berdiri, jangkauan tangan kedepan, pangkal ketangan, leher tangan.

4. Uji Keseragaman Data.

Pengujian uji keseragaman dan merupakan pengujian untuk memastikan bahwa data yang didapat berasal dari sistem yang sama.
5. Uji Kecukupan Data

Uji kecukupan data diperlukan untuk memastikan bahwa yang telah dikumpulkan dan disajikan dalam laporan penimbangan tersebut adalah cukup secara obyektif . Untuk itu, pengujian kecukupan data dilakukan dengan berpedoman pada konsep statistic, yaitu tingkat ketelitian dan tingkat keyakinan.

6. Uji Kenormalan.

Uji Kernomal atau Normalitas adalah sebuah uji yang dilakukan dengan tujuan untuk menilai sebaran data pada sebuah kelompok data atau variabel, apakah sebaran data tersebut berdistribusi normal atau tidaknya. Uji statistik normalitas yang dapat digunakan diantaranya adalah Chi-Square.

\section{HASIL DAN PEMBAHASAN}

Pengumpulan data pada penelitian ini dilakukan dengan cara melakukan pengamatan langsung di Perusahan UKM CV. XYZ. Data yang dikumpulkan berupa data Karakteristik Pekerja Pabrik dan data Kuisioner yang diamatin langsung oleh peneliti terhadap para pekerja pengkilap panci.

\subsection{Karakteristik PekerjaPabrik CV. XYZ Medan Pancing.}

Data keluhan muskuloskeletal diukur dengan menggunakan Kuisioner Nordic Body Map yang dilakukan pada pekerja di CV. XYZ Medan Pancing . Adapun hasil Rekapitulasi dari data kuisioner pada pekerja dapat diliat pada tabel.1 sebagai berikut:

Tabel.1 Hasil Rekapitulasi Data Kuisioner 


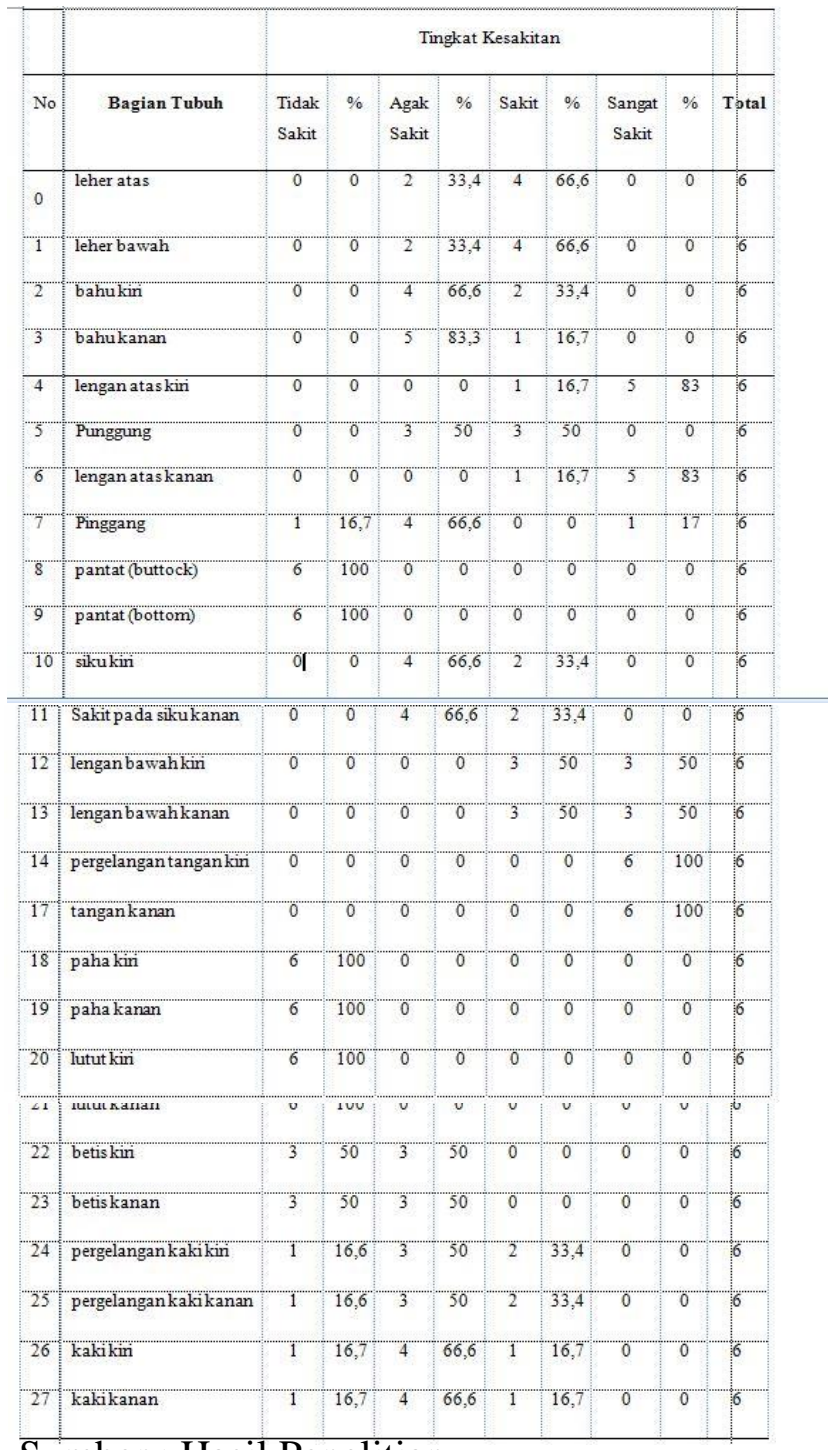

Sumber : Hasil Penelitian

Berdasarkan tabel diatas diketahui bahwa pekerja mengalami keluhan muskuloskeletal yang dialami pekerja pengkilap panci berada pada kategori sakit terbanyak adalah pada leher atas dan leher bawah sebanyak 4 ( $66,7 \%)$. Pada kategori sangat sakit terbanyak adalah pada tangan kanan dan pergelangan tangan kanan , tangan kiri dan pergelangan tangan kiri sebanyak 6 ( $100 \%$ ).

\subsection{Postur Kerja}

Postur Kerja diukur dengan menggunakan metode REBA. Hasil pengukuran postur kerja dengan metode REBA dapat dilihat dibawah ini.

Tabel 2. Nilai Hasil Akhir REBA xl Sistem Teknik Industri, Vol. 20 No. 2, Juli 2018

ISSN 1411 - 5247

\begin{tabular}{|c|c|c|}
\hline Nama & $\begin{array}{l}\text { Nilai } \\
\text { Akhir } \\
\text { REBA }\end{array}$ & Keterangan \\
\hline Kasman & 10 & \\
\hline $\begin{array}{l}\text { Supardi } \\
\text { Jumiran }\end{array}$ & 9 & $\begin{array}{l}\text { Beresiko Tinggi , } \\
\text { menyelidiki } \\
\text { menerapkan perubahan }\end{array}$ \\
\hline Yetno & 10 & Resiko Sangat Tinggi \\
\hline Yadi & 9 & $\begin{array}{c}\text { Perlu menerapkan } \\
\text { Perubahan }\end{array}$ \\
\hline Hendri & 11 & \\
\hline
\end{tabular}

Sumber : Hasil Penelitian

\subsection{Data Antropometri}

Adapun data hasil rekapitulasi data antropometri pada pekerja CV. XYZ Medan Pancing dapat diliat pada tabel sebagai berikut.

Tabel 3. Hasil Rekapitulasi Antropometri

\begin{tabular}{|c|c|c|c|c|c|c|c|c|c|c|}
\hline No. & Nama & Umur & $\begin{array}{l}\text { Masa } \\
\text { Kerja }\end{array}$ & $\begin{array}{l}\text { Lebar } \\
\text { Bahu } \\
\text { (lb) }\end{array}$ & $\begin{array}{l}\text { Tinggi } \\
\text { Badan } \\
\text { Tegak } \\
\text { (tbt) }\end{array}$ & $\begin{array}{c}\text { Tinggi } \\
\text { Siku } \\
\text { Berdiri } \\
\text { (tsb) }\end{array}$ & $\begin{array}{c}\text { Tinggi } \\
\text { Lutut } \\
\text { Berdiri } \\
\text { (tlbb) }\end{array}$ & \begin{tabular}{c|} 
Panjang \\
Lengan \\
dari \\
awal \\
sampai \\
ujung \\
(Jtd)
\end{tabular} & $\begin{array}{c}\text { Diameter } \\
\text { Lingkar } \\
\text { genggaman } \\
(\mathrm{dlg})\end{array}$ & $\begin{array}{c}\text { Panjang } \\
\text { Siku } \\
\text { sampai } \\
\text { ujung } \\
\text { Tangan } \\
\text { ( jktd) }\end{array}$ \\
\hline 1 & Kastnan & 44 & 12 & 48 & 170 & 115 & 55 & 65 & 2 & 45 \\
\hline 2 & Yetri:0 & 35 & 8 & 42,2 & 165 & 105 & $45^{\prime}$ & 60 & 1,5 & 42 \\
\hline 3 & Supardi & 42 & 8 & 45 & 168 & 109 & 49 & 76 & 1,5 & 42 \\
\hline 4 & Jumiran & 36 & 9 & 31,7 & 172 & 111,5 & 54 & 73,5 & 2 & 46 \\
\hline 5 & Yad & 32 & 8 & 45 & 169 & 106 & 43 & 70 & 1,5 & 43 \\
\hline $5^{6}$ & Henari & & & & & & 45 & 66 & 1.5 & 42 \\
\hline
\end{tabular}

\subsection{Metode Pengolahan Data}

Dalam pengolahan data hasil pengukuran, maka akan digunakan formula statistik untuk melakukan pengukuran dan pengujian serta perhitungan antara lain:

\section{a. Uji Kenormalan ( Normalitas )}

Uji Normalitas dilakukan untuk melihat data apakah berdistribusi normal atau tidak. Jika data berdistribusi normal, analisis statistik yang digunakan adalah uji parametrik, namun jika data tidak berdistribusi normal analisis statistik yang digunakan adalah uji non parametrik. Dan dikatakan berdistribusi normal apabila nilai variabel > 0,05 maka 
ISSN 1411 - 5247

data harus menggunakan uji parametrik. Begitu juga sebaliknya dikatakan berdistribusi tidak normal jika nilai variabel $<0,05$ maka data harus menggunakan uji non parametrik.

Tabel 4. Uji Kenormalan Pada Lebar Bahu

\begin{tabular}{|c|c|c|c|c|c|c|c|c|c|}
\hline \multirow{2}{*}{$\begin{array}{c}\text { No } \\
\text { Kelas }\end{array}$} & \multirow[t]{2}{*}{ Batas Kelas } & \multicolumn{2}{|c|}{ Z } & \multicolumn{2}{|c|}{$\mathrm{Pa}$} & \multirow{2}{*}{$\begin{array}{l}\text { Luas } \\
\text { Kelas }\end{array}$} & \multirow[t]{2}{*}{$\mathrm{Ei}$} & \multirow[t]{2}{*}{$\mathrm{Oi}$} & \multirow{2}{*}{$x^{2}=\frac{(o i-E i)^{2}}{\vec{E} i}$} \\
\hline & & $\mathrm{Zb}$ & $\mathrm{Za}$ & $\mathrm{Pb}$ & $\mathrm{Pa}$ & & & & \\
\hline 1 & $30,0-33,5$ & $-2,50$ & $-1,73$ & 0,0062 & 0,0418 & $\overline{0,036}$ & 1,2816 & 4 & 5,766 \\
\hline 2 & $33,5-36,5$ & $-1,73$ & $-1,08$ & 0,0418 & 0,1401 & 0,098 & 3,5388 & 2 & 0,669 \\
\hline 3 & $36,5-39,5$ & $-1,08$ & $-0,42$ & 0,1401 & 0,3372 & 0,197 & 7,0956 & 1 & $5,23\}$ \\
\hline 4 & $39,5-42,5$ & $-0,42$ & 0,24 & 0,3372 & 0,5948 & 0,258 & 9,2736 & 12 & 0,804 \\
\hline 5 & $42,5-45,5$ & 0,24 & 0,90 & 0,5948 & 0,8159 & 0,221 & 7,9596 & 13 & 3,192 \\
\hline 5 & $45,5-48,5$ & 0,90 & 1,56 & 0,8159 & 0,9406 & 0,125 & 4,4892 & 3 & 0,494 \\
\hline 6 & $48,5-51,5$ & 1,56 & 2,22 & 0,9406 & 0,9868 & 0,046 & 1,6632 & 1 & 0,264 \\
\hline & umlah & & & & & & & 36 & 16,423 \\
\hline
\end{tabular}

Sumber : Hasil Penelitian

Berdasarkan hasil tabel diatas dapat dilihat bahwa nilai signifikansi dari berdistribusi normal apabila nilai variabel > 0,05, sehingga hasil uji normalitas pada dimensi dapat dikatakan data berdistribusi normal.

\section{b. Uji Keseragaman}

Uji keseragaman suatu pengujian statistik untuk melihat apakah data berasal dari suatu sistem sebab yang sama (seragam). Pengujian dilakukan dengan mencari batas kontrol atas dan batas kontrol bawah sesuai dengan tingkat ketelitian dan kepercayaan yang diberikan.

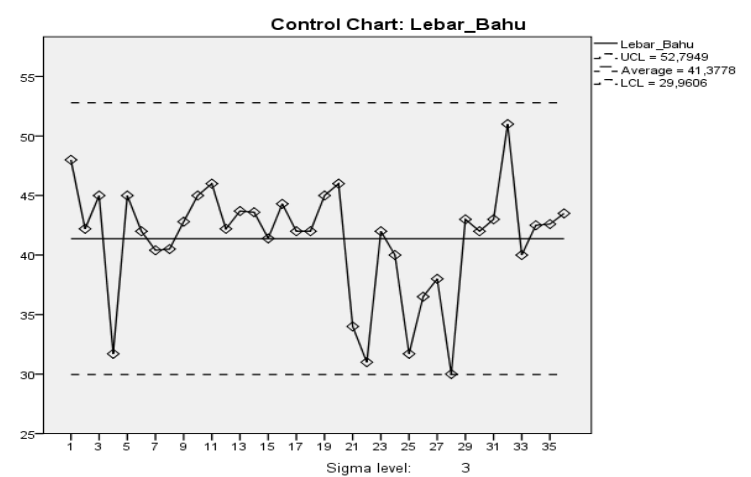

Gambar 1. Diagram. Lebar Bahu

Dan untuk hasil data yang lain dapat dilihat pada tabel dimana data tersebut sudah direkapitulasi bahwa semua data berasal dari suatu sistem sebab yang sama (seragam).

Tabel 5. Keseragaman Data

No. Nama

Keterangan

\begin{tabular}{lll}
\hline 1 & Lebar Bahu & Seragam \\
2 & Tinggi Badan Tegak & Seragam \\
3 & Tinggi Siku Berdiri & Seragam
\end{tabular}

4 Tinggi Lutut Berdiri Seragam

5 Panjang Lengan Awal Seragam Ujung

6 Diameter Genggaman Seragam

7 Panjang Siku Ujung Seragam Tangan

Sumber : Hasil Penelitian

Dari Tabel diatas dapat dilihat, dari setiap pernyataandapat disimpulkan bahwa semua konsep pengukuran data tersebut seragam dimana dapat dilihat dari diagram batas kontrol atas dan batas kontrol bawah.

\section{c. Uji Kecukupan Data}

Uji kecukupan data digunakan untuk melihat apakah data yang diambil sudah mencukupi atau belum sesuai dengan tingkat ketelitian serta kepercayaan yang diinginkan.

Contoh dengan ketelitian $10 \%$ dan tingkat kepercayaan $95 \%$.

$N^{\prime}=\left\lceil\left.\frac{k / s \sqrt{N \sum x^{2}-\left(\sum x\right)^{2}}}{\sum x}\right|^{2}\right.$

Dimana:

$\mathrm{k}=$ Tingkat Keyakinan $(99 \% \approx 3,95 \% \approx 2)$

$\mathrm{s}=$ Derajat Ketelitian

$\mathrm{N}=$ Jumlah Data Pengamatan

N' = Jumlah Data Teoritis

$\mathrm{x}=$ Data Pengamatan

Jika $\mathrm{N}^{\prime} \leq \mathrm{N}$ maka data dianggap cukup, namun jika $\mathrm{N}^{\prime}>\mathrm{N}$ data tidak cukup (kurang) dan perlu dilakukan penambahan data.

1. Uji Kecukupan Pada Lebar Bahu $N^{*}=\left[\frac{95 / 10 \sqrt{3662424,32-2218908,16}}{1489,6}\right] 2$

$N^{\prime}=\left[\frac{0,2 \times 100 \sqrt{3662424,32-2218908,16}}{1489,6}\right] 2$ $\mathrm{N}^{\circ}=\left[\frac{20 \sqrt{28367,36}}{1489,6}\right] 2$ 


\section{$\mathrm{N}^{\prime}=5,114$}

Dari hasil perhitungan diatas dapat dilihat, bahwa dari setiap perhitungan pernyataan Jika $\mathrm{N}^{\prime} \leq \mathrm{N}$ maka data dianggap cukup, namun jika $\mathrm{N}^{\prime}>\mathrm{N}$ data tidak cukup (kurang) dan perlu dilakukan penambahan data. Dari data didapat nilai variabel lebih dari N'>36 dinyatakan tidak cukup atau tidak reliabel dan nilai variabel lebih dari $\mathrm{N}^{\prime}<36$ dinyatakan cukup atau reliabel . Dengan demikian dapat disimpulkan bahwa semua perhitungan dari tabel diatasadalah reliabel dikarenakan N'<36.

\section{d. Perhitungan Persentil}

Untuk menentukan uji persentil diperlukan 2 buah langkah berdasrkan 2 kemungkinan $\mathrm{p}$ yaitu:

Bila p normal, maka :

$\mathrm{P}$ (5) =Untuk persentil ke 5(ukuran data terendah)

$\mathrm{P}(50)=$ Untuk persentil ke 50(ukuran data sedang)

$\mathrm{P}(95)=$ Untuk persentil ke 95(ukuran data tertinggi)

Perhitungan Persentil Pada Lebar Bahu.

$$
\begin{aligned}
\mathrm{P}_{5} & =\mathrm{M}+\mathrm{Sd} . \mathrm{Z} \\
& =41,39+4,43 *-1.64 \\
& =34,11 \\
\mathrm{P}_{50} & =\mathrm{M}+\mathrm{Sd} . \mathrm{Z} \\
& =41,39+4,43 *(0) \\
& =41,39 \\
\mathrm{P}_{95} & =\mathrm{M}+\mathrm{Sd} . \mathrm{Z} \\
& =41,39+4,43 * 1,64 \\
& =48,66
\end{aligned}
$$

Tabel 6. Hasil Perhitungan Persentil

\begin{tabular}{|l|l|l|l|}
\hline \multirow{2}{*}{ Nama } & \multicolumn{3}{|c|}{ PERSENTIL } \\
\cline { 2 - 4 } & $\mathrm{P}(5)$ & $\mathrm{P}(50)$ & $\mathrm{P}(95)$ \\
\hline Lebar Bahu & 34,11 & 41,39 & 48,66 \\
\hline $\begin{array}{l}\text { Tingg Bdn } \\
\text { Tegak }\end{array}$ & 155,77 & 164,56 & 173,35 \\
\hline $\begin{array}{l}\text { Tinggi Siku } \\
\text { Berdiri }\end{array}$ & 95,11 & 106,04 & 116,97 \\
\hline
\end{tabular}

ISSN 1411 - $\mathbf{5 2 4 7}$

\begin{tabular}{|l|l|l|l|}
\hline $\begin{array}{l}\text { Tinggi Lutut } \\
\text { Berdiri }\end{array}$ & 38,88 & 45,76 & 52,65 \\
\hline $\begin{array}{l}\text { Panjang Awgan Awal } \\
\text { Lengan } \\
\text { Ujung }\end{array}$ & 65,95 & 75,88 & 85,77 \\
\hline $\begin{array}{l}\text { Diameter } \\
\text { Genggaman }\end{array}$ & 1,36 & 1,74 & 2,11 \\
\hline $\begin{array}{l}\text { Panjang Siku } \\
\text { Sampai Ujung } \\
\text { Tangan }\end{array}$ & 38,68 & 43,52 & 48,37 \\
\hline
\end{tabular}

Rancangan Desain Mesin Perbaikan Alat Pengkilap Panci.

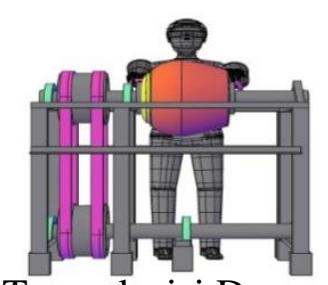

Tampak sisi Depan

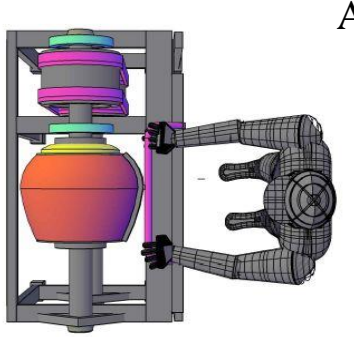

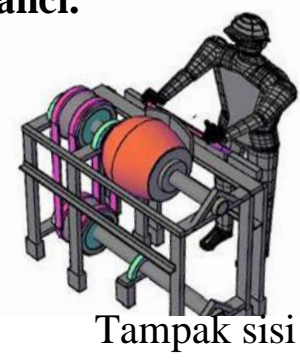

Atas

\begin{tabular}{|c|c|c|c|c|c|c|}
\hline No. & Aktual & $\begin{array}{l}\text { Skor } \\
\text { Reba }\end{array}$ & Keterangan & Usulan & $\begin{array}{l}\text { Skor } \\
\text { Reba }\end{array}$ & Keterangan \\
\hline 1 & Hendri & 11 & $\begin{array}{c}\text { Resilko } \\
\text { Sangat } \\
\text { Tinggi, Perlu } \\
\text { menerapkan } \\
\text { perrubahan }\end{array}$ & $\begin{array}{l}\text { Rancangan } \\
\text { Desain }\end{array}$ & 5 & $\begin{array}{c}\text { Resiko } \\
\text { Rendah, } \\
\text { perubahan } \\
\text { mungkin } \\
\text { diperlukan }\end{array}$ \\
\hline
\end{tabular}

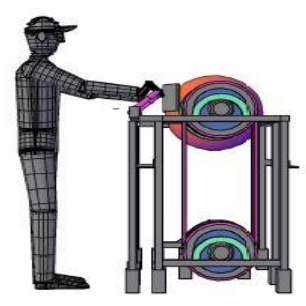

Tampak sisi Atas Tampak Sisi Kanan Gambar 8. Desain MesinPengkilap Panci Usulan

\section{Hasil dan Pembahasan}

\subsection{Postur Kerja Usulan}

Tabel 7. Hasil Perbandingan Aktual dan Usulan

Sumber : Hasil Penelitian 
Dari hasil analisis postur kerja setelah dilakukan perbaikan fasilitas kerja dapat dilihat bahwa resiko pekerjaan berkurang dari kategori sangat beresiko menjadi resiko rendah.

\section{SIMPULAN}

Berdasarkan hasil penelitian yang telah dilakukan, maka dapat ditarik simpulan yang diperoleh dari 6 orang pekerja pengkilap panci

di Pabrik UKM CV. XYZ Medan Pancing pada Tahun 2017.

Berdasarkan hasil penelitian yang dilakukan pada sikap kerja pada mesin pengkilap panci di CV. XYZ Medan Pancing dengan menggunakan metode REBA ( Rapid Entire Body Assessment) didapatkan bahwa sikap kerja pekerja pengkilap panci berada pada kategori resiko tinggi dan resiko sangat tinggi . Kategori tersebut didapat dari hasil skor REBA yang menunjukkan sikap kerja pengkilap panci berada pada skor kategori tinggi 9 dan skor kategori sangat tinggi 11 dan perlunya menerapkan perubahan. Dari hasil kuesioner SNQ (Standart Nordic Questionnaire) pada 6 orang pekerja menunjukkan bahwa keluhan muskuloskeletal yang dialami pekerja pengkilap panci berada pada kategori sakit terbanyak adalah pada leher atas dan leher bawah sebanyak $4(66,7 \%)$. Pada kategori sangat sakit terbanyak adalah pada tangan kanan dan pergelangan tangan kanan , tangan kiri dan pergelangan tangan kiri sebanyak 6 ( $100 \%$ ). Dari hasil rancangan desain usulan didapat bahwa keluhan muskuloskeletal yang di alami pekerja berada pada skor 5 yang merupakan kategori resiko rendah perubahan diperlukan.

\section{DAFTAR PUSTAKA}

Anies, 2014. Kedokteran Okupasi Berbagai Penyakit Akibat Kerja dan Upaya Penanggulangan dari Aspek
Kedokteran. Yogyakarta: ArRuzz Media.

Bedu, H.H.S.; Russeng, S.S. ;Rahim, M.R. 2013. Faktor yang Berhubungan dengan Gangguan Musculoskeletal pada Cleaning Service RSUP Dr. Wahidin Sudirohusodo Makassar. Jurnal. Makassar: Fakultas Kesehatan Masyarakat Universitas Hasanuddin. http://repository.unhas.ac.id/bitstream/ handle. Diakses 19 Agustus 2017.

Bukhori, E. 2010. Hubungan Faktor Risiko Pekerjaan Dengan Terjadinya Keluhan Musculoskeletal Disorders (MSDs) Pada Tukang Angkut Beban Penambang Emas Di Kecamatan Cilograng Kabupaten Lebak. Skripsi. Jakarta: Fakultas Kedokteran Ilmu Kesehatan Universitas Islam Negeri Syarif Hidayatullah.

Gempur. 2013. Ergenomi Terapan. Jakarta : Prestasi Pustaka Publisher.

Hardianto, I. Yassierli. 2014. Ergonomi Suatu Pengantar. Bandung : PT. Remaja Rosdakarya.

Nurmanto, E. 2004. Ergonomi Konsep Dasar dan Aplikasinya. Surabaya : Guna Widya.

Qutubuddin, S.M. dan A.C.S, Kuma. 2013. Ergonomic Evaluation of Tasks Performed by Workers in Manual Brick in Karnataka, India. Global Journal of Researches in Engineering vol 13: 35-40. https://globaljournals.org/GJRE_Volu me13/4-ErgonomicEvaluation-ofTasks-Performed. Diakses 6 Februari 2018. 